\section{Educating the data user: classroom support services}

by Bobbie Pollard ${ }^{1}$

Baruch College, City University of New York
${ }^{1}$ Presented at the International Association for Social Science lnformation Service and Technology (IASSIST) Conference held in Washington, D.C., May 26-29, 1988
"You people are really in the business of selling information" was a recent comment from a faculty member at Baruch College after a presentation to his class of 98 students. We certainly are in the business of marketing information. Indeed, our Classroom Support Services Program is an active and proactive one. During the past academic year we conducted nearly 200 Library Research Workshops. Over 6000 students were spoken to directly and many more were reached through printed literature such as Resources for Research and Access Guides. Currently, twenty-two departments in the college use our services, including: Marketing, Management, Business Communications, Marketing, Education, Speech, and English, to name only a few.

The goals of the Classroom Support Services are to inform assist students in their search for information for assignments in the various classes, and, equally important, to provide them with an understanding of how information is organized in the various disciplines. These information seeking skills help students develop confidence in the use of bibliographic and quantitative sources, not only for their college assignments but throughout their their later careers.

The library research workshops are assignment driven and given at the request of faculty. Therefore the success of the program depends on how well faculty are informed about the importance of students learning how to do research. We advertise our program to faculty through a flyer and by attending departmental meetings. A lot of our publicity is done by word of mouth; a faculty member who is pleased with the program tells his colleague. Most of the requests come from our undergraduate faculty. We only do library research workshops for classes with research assignments (sometimes these assignments are made up by the librarians and faculty member together), and we require faculty members to be present at the workshops. 
The content of a typical library research workshop includes the following: (1) the importance of information and an outline of a research strategy with examples of tools appropriate to the subject discipline, or topics that the students are researching; and (2) practice in the library or online classroom using the materiais and techniques discussed in the workshop. Practice is essential because it is effective in clearing confusion and misunderstandings about the information presented in the workshop. Most workshops are seventy-five minutes in length.

The majority of the subjects taught at Baruch require students to use some type of public data. The basic bibliographies and keys to finding information which are tailored to the content of the assignments and/or the course are called Resources for Research. Most of the Resources for Research include government docments or an access tool that refers to government documents as sources of information. For example, the most heavily used Resources for Research, "The Basic Research Strategy", lists the Public Affairs Information Service Bulletin (PAIS) which indexes several government documents. The one entitled "Company and Industry" includes many other public data sources as well. Others that include listings of public data sources are: "International Marketing," "Statistics", "Marketing", "Education", "International Business", and "Business Journalism".

Public data are presented to students as being plentiful, reasonable, and generally easily accessible. Because Baruch College is one of the largest business schools, it is not surprising that our students need information on companies, industries, marketing, and statistics. Even the English classes tend to do research on social science issues which required access to government data. In the majority of workshops some information on government data is presented, but it is a crucial source of information in the following classes: Business
Communications, Marketing, International Business, and Business Journalism. Below is a sampling of the kinds of information sought most by students in these classes, with some representative public data sources about which students are informed.

The usual assignment in the business communications and marketing classes requires students to research companies, industries, products, and demographic data. They need information on sales, maketing, a financial profile, market share information, etc. In these classes, students are introduced to a variety of public data sources such as annual reports of publicly held companies, and U. S. Department of Commerce publications such as the $\underline{U}$. S. Industrial Outlook. For statistical information on both products and industries students are advised to begin with the Statistical Abstract which serves as a summary and guide to most federal statistics including census data. Predicasts $F$ \& $S$ Index of Corporations and Industries, PAIS, and other indices such the Business Periodicals Index identify governmental data in periodicals. For information in books, students are shown how to look up information by subject, e.g. U. S. industries, or by governmental agency, e.g. U. S. Department of Commerce.

In some market research classes, students are required to develop questionnaires. The instructors suggest that they look at many different types of questionnaires. The Inter-University Consortium for Political and Social Research (ICPSR) codebooks such as The Quality of American Life are very helpful to students in completing these assignments.

In international business and international marketing classes, students study conditions for business in foreign countries and the import and export trade. For assignments in these classes, students are introduced to the numerous publications produced by the U. S. Department of State and U. S. Deparment of 
Commerce. Background Notes, Overseas

Business Reports, Marketing in ...., and Foreign Economic trends and Their Implications for the United States are but a few of the public data sources taught in these classes.

The business journalism class produces a national periodical called Dollars and Sense. The students research and write articles using mostly primary sources. Therefore, they need general background information, names of experts to interview, and a great deal of statistical data to back up their theses. The topics in the latest issue of this magazine, AIDS, women entrepreneurs, illiteracy in the workplace, West Indian businesses, are representative of the articles that students write for this publication. Public data sources on national and local levels are used heavily. Students are introduced to the following indices which are excellent for identifying statistical information to support a point of view or to document a trend. The indices are the American Statistical Index which identifies statistical information in over 400 federal governmental agencies, and Statistical Reference Index, an excellent source of statistical data published by local governments. For example, Business Statistics by the New York State Department of Commerc conttained important statistical data on West Indian businesses in New York. Students are also made familiar with many other government publications through the use of the Monthly Catalog, CIS Index, and a multitude of other government directories. $\square$ 